\title{
Physiological potential of eggplant seeds ${ }^{1}$
}

\author{
Magnólia de Mendonça Lopes²*, Clíssia Barboza da Silva², Roberval Daiton Vieira ${ }^{2}$
}

\begin{abstract}
The use and efficiency of vigor tests depend on the plant species and the development and, or adjustment of methodology, to obtain efficient procedures for evaluating seed physiological potential. The objective of this study was to compare different methods for evaluating the physiological potential of eggplant seeds (Solanum melongena $\mathrm{L}$ ). Six seed lots of the "Comprida Roxa" cultivar were submitted to the following tests: germination, first count germination, seedling emergence, controlled deterioration (18, 21 and $24 \%$ for 24 and 48 hours at $45{ }^{\circ} \mathrm{C}$ ), accelerated ageing (AA) and saturated salt accelerated ageing (both at 41 and $45^{\circ} \mathrm{C}$ for 24,48 and 72 hours) and electrical conductivity ( 25 seeds, 50 and $75 \mathrm{~mL}$ of water for 1,2 , $4,8,12,16$ and 24 hours of imbibition at $25^{\circ} \mathrm{C}$ ). The first count test provided preliminary information on seed germination and the other tests, in general, gave similar results for seedling emergence. It was concluded that the physiological potential of eggplant seeds can be evaluated using AA for $48 \mathrm{~h} / 41{ }^{\circ} \mathrm{C}$ and controlled deterioration at $24 \%$ moisture content/ $24 \mathrm{~h} / 45^{\circ} \mathrm{C}$. The best conditions for the electrical conductivity test on eggplant seed are using 25 seeds in $50 \mathrm{~mL}$ of water for four hours at $25^{\circ} \mathrm{C}$.
\end{abstract}

Index terms: Solanum melongena L, vegetable crop, vigor.

\section{Potencial fisiológico de sementes de berinjela}

\begin{abstract}
RESUMO - A eficiência dos procedimentos na avaliação do potencial fisiológico de sementes depende do desenvolvimento e, ou do ajuste de metodologia para as diferentes espécies. Assim, o objetivo da pesquisa foi comparar diferentes métodos para a avaliação do potencial fisiológico de sementes de berinjela (Solanum melongena L). Para tanto, seis lotes de sementes da cultivar Comprida Roxa foram submetidos aos testes de germinação, primeira contagem da germinação, emergência de plântulas, deterioração controlada $\left(18,21\right.$ e $24 \%$ por 24 e 48 horas a $45^{\circ} \mathrm{C}$ ), envelhecimento acelerado (com e sem o uso de solução saturada de $\mathrm{NaCl}$ a 41 e $45^{\circ} \mathrm{C}$ por 24, 48 e 72 horas) e condutividade elétrica ( 25 sementes em 50 ou $75 \mathrm{~mL}$ de água por 1, 2, 4, 8, 12, 16 e 24 horas, à $25^{\circ} \mathrm{C}$ ). A primeira contagem de germinação permitiu a obtenção de informações preliminares sobre o vigor das sementes e os demais testes realizados, em geral apresentaram similaridade com a emergência de plântulas. Concluiu-se que o potencial fisiológico de sementes de berinjela pode ser avaliado pelos testes de envelhecimento acelerado tradicional $48 \mathrm{~h} / 41^{\circ} \mathrm{C}$; deterioração controlada a $24 \% / 24 \mathrm{~h} / 45^{\circ} \mathrm{C}$ e condutividade elétrica com 25 sementes em $50 \mathrm{~mL}$ de água, por quatro horas, a $25^{\circ} \mathrm{C}$.
\end{abstract}

Termos para indexação: Solanum melongena L, hortaliça, vigor.

\section{Introduction}

Eggplant (Solanum melongena L.) is a solanaceous plant originating from the tropical regions of Asia and has been cultivated for many centuries by the Chinese and Arabs. Eggplant is grown throughout the year in Brazil although the planted area is not very significant and one of the main production problems is field crop establishment. Germination problems and a reduced plant stand have been attributed to poor lot quality due to the uneven ripening of eggplant seeds and fruits, which result in uneven seed germination (Filgueira, 2008).

Seed lot quality is routinely evaluated using the germination test, done under favorable moisture, temperature and substrate conditions, which provides a maximum potential for normal seedling production (Carvalho and Nakagawa, 2000). However, this test may be estimating field performance incorrectly, since field conditions are not always favorable and, consequently, seedling emergence may be significantly less than that observed from the germination test in the laboratory.

Therefore, the tests which provide an estimate of seed performance in the field and, or in storage, are important for a seed quality control program. These seed vigor tests are recommended for identifying differences between lots, principally those which have a similar germination percentage (Marcos-Filho, 2005).

${ }^{1}$ Submitted on 08/29/2012. Accepted for publication on 10/29/2012.

${ }^{2}$ Departamento de Produção Vegetal, UNESP/FCAV, 14884-900 - Jaboticabal, SP, Brasil.

*Corresponding author: <magnolia_lopes@yahoo.com.br> 
Studies on the physiological potential of different horticultural seeds has shown that the germination of these seeds does not always reach the minimum commercial standard required for each species (Marcos-Filho, 2005), suggesting that more sensitive tests to analyze seed physiological potential are necessary.

There is no standard test for evaluating the seed vigor of every species and the number of species which have a recommended vigor test is small, particularly for horticultural seeds, where only the electrical conductivity test for pea seeds is available (Baalbaki et al., 2009).

It is recommended that vigor be evaluated with two or more tests since they evaluate different aspects of seed behavior (Marcos-Filho, 2005). It is difficult for a single test to classify lots for vigor and safely evaluate performance during storage or in the field. Therefore, the standardization of vigor tests is important because as cultural management techniques become more sophisticated, the need to use high quality seed increases.

Therefore, considering the scarcity of studies offering a suitable methodology for determining the vigor of eggplant seed, the objective of this study was to compare different methods for evaluating the physiological potential of these seeds.

\section{Material and Methods}

This study was carried out at the Seed Analysis Laboratory of the Plant Production Department of UNESP, Jaboticabal Campus, using six lots of cv. Comprida Roxa eggplant seeds in the following tests:

Water content: performed in an oven at $105 \pm 3{ }^{\circ} \mathrm{C} / 24 \mathrm{~h}$ (Brasil, 2009), using two subsamples of approximately $2 \mathrm{~g}$ of seeds from each lot. The results were expressed as a percentage for each lot (wet basis). The initial variation between lots ranged from 7.6 to $7.8 \%$.

Germination test: done with 200 seeds (four subsamples of 50 seeds $)$ per lot, sown in a plastic container $(11.0 \mathrm{x} 11.0 \mathrm{x}$ $3.0 \mathrm{~cm}$ ), on two leaves of filter paper moistened with distilled water, at a ratio of three times the weight of dry paper and set to germinate at $20-30{ }^{\circ} \mathrm{C}$. Counts were made 14 days after sowing and the results were expressed as a percentage of normal seedlings (Brasil, 2009).

First germination count: done together with the germination test, calculating the percentage of normal seedlings on the seventh day after sowing, with the results expressed as a percentage of normal seedlings (Brasil, 2009).

Accelerated aging (traditional procedure): done with 200 seeds per lot, distributed on aluminium mesh trays fixed inside each plastic container $(11.0 \times 11.0 \times 3.0 \mathrm{~cm})$, acting as an individual compartment (mini-chamber). Inside the plastic container, $40 \mathrm{~mL}$ of water were added and the containers were closed with the seeds inside and taken to a BOD-type germination chamber. The seeds were aged at 41 and $45{ }^{\circ} \mathrm{C}$ for 24, 48 and 72 hours and then submitted to the germination test. An evaluation was made seven days after sowing and the results expressed as the mean percentage of normal seedlings for each lot. The uniformity of the test conditions was checked by determining the seed water contents after aging, which ranged from 34.6 to 36.6 and 36.4 to 38.9 , at 41 and $45^{\circ} \mathrm{C}$ respectively.

Accelerated aging (saturated salt solution): as described for the conventional test but with $40 \mathrm{~mL}$ of saturated $\mathrm{NaCl}$ solution added to the bottom of each plastic container instead of water (Jianhua and McDonald, 1997). This solution was obtained by diluting $40 \mathrm{~g}$ of $\mathrm{NaCl}$ in $100 \mathrm{~mL}$ of water. The evaluation was made seven days after sowing and the results expressed as a mean percentage of normal seedlings for each lot. The uniformity of the test conditions was checked by determining the seed water contents after aging, and this ranged from 9.1 to $9.8 \%$ and 9.3 to $10.2 \%$, at 41 and $45^{\circ} \mathrm{C}$ respectively.

Controlled deterioration: seed water contents were first adjusted to 18, 21 and 24\% using the humid air method (Rossetto et al., 1995). A seed sample from each lot was placed on the mesh in a plastic container containing $40 \mathrm{~mL}$ of distilled water. The containers were closed and kept in a chamber at $20{ }^{\circ} \mathrm{C}$, with successive weighings being done at one hour intervals to monitor seed water content until the desired values were reached.

The lot samples were then hermetically sealed in aluminized plastic containers and kept for five days in a cold chamber $\left(10^{\circ} \mathrm{C}\right.$ and $40 \% \mathrm{RH}$ ), to reach hygroscopic equilibrium. After this period, the samples were placed in a water-bath at $45^{\circ} \mathrm{C}$ for 24 and 48 hours (Powell, 1995). At the end of this period, the containers were removed and placed in a desiccator for 30 minutes to reduce the temperature, after which the germination test was performed, with counting on the seventh day after sowing. To monitor the test, the seed water contents were measured before and after the deterioration periods.

Electrical conductivity: the following variables were considered: number of seeds (25), volume of imbibed water (50 and $75 \mathrm{~mL}$ ) and period of imbibitions $(1,2,4,8,12,16$, 20 and 24 hours) at $25^{\circ} \mathrm{C}$. Evaluations were done with four subsamples, using previously weighed seeds to an accuracy of $0.001 \mathrm{~g}$. Electrical conductivity was measured with a model DM-31 Digimed ${ }^{\circledR}$ conductivity meter and the mean values for each lot were expressed in $\mathrm{mS} . \mathrm{cm}^{-1} \cdot \mathrm{g}^{-1}$ of seed. The readings for each subsample were taken soon after the material had been gradually removed from the incubator, carefully shaking each container in order to standardize the leached electrolytes in the 
solution (Vieira and Krzyzanowski, 1999; AOSA, 2002).

Seedling emergence: polystyrene trays ("isopor") with individual cells, containing commercial organic-mineral substrate (like Plantmax) were used and kept in a green house with a mean temperature of $26.03{ }^{\circ} \mathrm{C}$ and watered every three days. Four subsamples of 50 seeds were taken from each lot, with one seed per cell. Seedling emergence was evaluated 14 days after sowing by counting the number of emerged normal seedlings, evaluated according to the criteria adopted for the evaluation of the aerial part of normal seedlings from the germination test. The results were expressed as a percentage of normal seedlings.

The experimental design was completely random with four replications and the means were compared using the Tukey test $(p \leq 0.05)$. The analyses were done separately for each test. The data from the tests for germination, seedling emergence, controlled deterioration and accelerated aging were first transformed into arc sine 100/x, with the data being expressed in their original values.

\section{Results and Discussion}

There was no differentiation between the seed lots for the germination test (Table 1). Although the germination values observed were high, this does not necessarily mean that the lots had a high vigor since the germination test is done under favorable temperature and moisture conditions, allowing the lot to express its maximum potential for normal seedling production (Marcos-Filho, 2005).

Table 1. Initial quality of six lots (\%) of cv. Comprida Roxa eggplant seeds, evaluated from tests for germination, first germination count and seedling emergence in a green house.

\begin{tabular}{cccc}
\hline Lots & Germination & $\begin{array}{c}\text { First } \\
\text { germination } \\
\text { count }\end{array}$ & $\begin{array}{c}\text { Seedling } \\
\text { emergence }\end{array}$ \\
\hline 1 & $--------------1 \%$------------- \\
2 & $93 \mathrm{a}$ & $22 \mathrm{~b}$ & $78 \mathrm{ab}$ \\
3 & $94 \mathrm{a}$ & $35 \mathrm{~b}$ & $76 \mathrm{~b}$ \\
4 & $89 \mathrm{a}$ & $18 \mathrm{c}$ & $70 \mathrm{c}$ \\
5 & $96 \mathrm{a}$ & $52 \mathrm{a}$ & $80 \mathrm{ab}$ \\
6 & $90 \mathrm{a}$ & $45 \mathrm{a}$ & $88 \mathrm{a}$ \\
\hline C.V. $(\%)$ & $91 \mathrm{a}$ & $47 \mathrm{a}$ & $89 \mathrm{a}$ \\
\hline
\end{tabular}

Means followed by the same letter in the column are not significantly different according to the Tukey test at $5 \%$ probability.

For the first germination count, lots 4,5 and 6 were classified as having a better quality and lot 3 a lower quality
(Table 1). Although the first germination count may be considered an indicator of vigor, it is known that the reduction in germination speed is not included among the initial events of the seed deterioration process (Delouche and Baskin, 1973). This justifies the need to evaluate the quality of eggplant seed lots by more vigor tests, with the aim of detecting small differences between lot groups.

The seedling emergence data indicated lots 5 and 6 as having high vigor and lot 3 lower vigor. These results agree in general with those obtained from the first germination count. According to Marcos-Filho (2005), the seedling emergence is an indicator of the efficiency of tests to evaluate the physiological potential of seed lots.

An analysis of the results of the traditional accelerated aging test (Table 2, lower section), showed that the period of $48 \mathrm{~h}$ at $41{ }^{\circ} \mathrm{C}$ was more sensitive for separating lots by physiological potential since it was possible to observe vigor levels: high (lots 5 and 6) and low (lot 3). Ávila et al. (2006), studying radish seeds, also found that lots could be separated into different vigor levels using the traditional accelerated aging test after aging for 48 hours. Although there is an indication that lots can be separated according to vigor, this procedure was not considered very consistent and more detailed studies were recommended. This has been supported by Torres and Negreiros (2008), who could not differentiate eggplant seed lots using a similar procedure.

The aging test with saturated $\mathrm{NaCl}$ solution (Table 2, lower section) demonstrated that the 48 hour period at $41{ }^{\circ} \mathrm{C}$ was the most sensitive for dividing lots into different vigor levels, with lots 5 and 6 having a high quality and lot 2 a low quality. This was a different result to that obtained from the seedling emergence, which pointed to lot 3 as having a low physiological potential. Although the other procedures gave significant results, these were not sufficiently sensitive to stratify the eggpplant seed lots into levels of different physiological potentials.

The conditions of accelerated aging with salt solutions promote less drastic effects because the degree of seed deterioration is lower with lower levels of water content than those normally observed using the traditional method (Marcos-Filho, 2005). Therefore, the stress condition most evident, such as the use of saline solution, is provoked primarily by an increase in temperatures, which agrees with the results obtained by Jianhua and McDonald (1997), Rodo et al. (2000) and Panobianco and Marcos-Filho (2001).

In the controlled deterioration test (Table 3 ), it was found that, generally, the combination $24 \mathrm{~h} / 24 \%$ at $45{ }^{\circ} \mathrm{C}$ showed a tendency which was compatible with the ranking of the lots with the first germination count and seedling emergence tests 
(Table 1), and it was considered the most promising test. Therefore, the classification of lots (5 and 6) as high quality and low quality (lot 3 ) was possible. These results confirm those of various authors for horticultural seeds, who declare that the adjustment of seed water content to $24 \%$ was the most suitable for performing the test on sugar beet, bell pepper, tomatoes and bur cucumber seeds (ISTA, 1995; Panobianco and MarcosFilho, 1998; Panobianco and Marcos-Filho, 2001 and Torres, 2005). On the other hand, Bhéring et al. (2000) found that in cucumber seeds this water content was only efficient when doing the controlled deterioration test and with the seeds submitted to 48 hours of conditioning in a water-bath.

Table 2. Vigor (\%) evaluated by the accelerated aging test (traditional and with saline solution) in six lots of cv. Comprida Roxa eggplant seeds.

\begin{tabular}{|c|c|c|c|c|c|c|}
\hline \multirow{3}{*}{ Lots } & \multicolumn{6}{|c|}{ Accelerated aging (traditional method) } \\
\hline & \multicolumn{3}{|c|}{$41^{\circ} \mathrm{C}$} & \multicolumn{3}{|c|}{$45^{\circ} \mathrm{C}$} \\
\hline & $24 \mathrm{~h}$ & $48 \mathrm{~h}$ & $72 \mathrm{~h}$ & $24 \mathrm{~h}$ & $48 \mathrm{~h}$ & $72 \mathrm{~h}$ \\
\hline & \multicolumn{3}{|c|}{ - } & \multicolumn{3}{|c|}{ 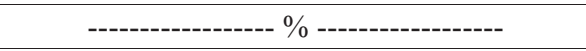 } \\
\hline 1 & $80 \mathrm{ab}$ & $85 \mathrm{ab}$ & $74 \mathrm{a}$ & $83 \mathrm{a}$ & $70 \mathrm{a}$ & $54 \mathrm{a}$ \\
\hline 2 & $78 \mathrm{~b}$ & $82 \mathrm{ab}$ & $71 \mathrm{a}$ & $72 \mathrm{~b}$ & $58 \mathrm{~b}$ & $60 \mathrm{a}$ \\
\hline 3 & $84 \mathrm{ab}$ & $70 \mathrm{c}$ & $78 \mathrm{a}$ & $75 \mathrm{~b}$ & $62 \mathrm{~b}$ & $62 \mathrm{a}$ \\
\hline 4 & $84 \mathrm{ab}$ & $80 \mathrm{~b}$ & $77 \mathrm{a}$ & $85 \mathrm{a}$ & $69 \mathrm{a}$ & $50 \mathrm{a}$ \\
\hline 5 & 93 a & $92 \mathrm{a}$ & $78 \mathrm{a}$ & $84 \mathrm{a}$ & $75 \mathrm{a}$ & $64 \mathrm{a}$ \\
\hline 6 & $95 \mathrm{a}$ & $92 \mathrm{a}$ & $73 \mathrm{a}$ & $79 \mathrm{a}$ & $72 \mathrm{a}$ & $50 \mathrm{a}$ \\
\hline \multirow[t]{2}{*}{$\mathrm{CV}(\%)$} & 8.0 & 5.2 & 7.6 & 8.0 & 7.5 & 14.7 \\
\hline & \multicolumn{6}{|c|}{ Accelerated aging (saturated saline solution) } \\
\hline \multirow{3}{*}{ Lots } & \multicolumn{3}{|c|}{$41^{\circ} \mathrm{C}$} & \multicolumn{3}{|c|}{$45^{\circ} \mathrm{C}$} \\
\hline & $24 \mathrm{~h}$ & $48 \mathrm{~h}$ & $72 \mathrm{~h}$ & $24 \mathrm{~h}$ & $48 \mathrm{~h}$ & $72 \mathrm{~h}$ \\
\hline & \multicolumn{3}{|c|}{ 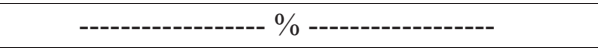 } & \multicolumn{3}{|c|}{ 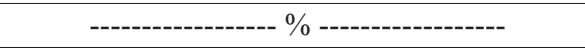 } \\
\hline 1 & $78 \mathrm{~b}$ & $77 \mathrm{~b}$ & $74 \mathrm{a}$ & $83 \mathrm{a}$ & $71 \mathrm{a}$ & $70 \mathrm{a}$ \\
\hline 2 & $75 \mathrm{~b}$ & $70 \mathrm{c}$ & $78 \mathrm{a}$ & $85 \mathrm{a}$ & $78 \mathrm{a}$ & $52 \mathrm{~b}$ \\
\hline 3 & $83 \mathrm{ab}$ & $87 \mathrm{ab}$ & $66 \mathrm{~b}$ & $78 \mathrm{a}$ & $65 \mathrm{a}$ & $68 \mathrm{a}$ \\
\hline 4 & $81 \mathrm{ab}$ & $80 \mathrm{ab}$ & $77 \mathrm{a}$ & $90 \mathrm{a}$ & $78 \mathrm{a}$ & $67 \mathrm{a}$ \\
\hline 5 & 93 a & $94 \mathrm{a}$ & $84 \mathrm{a}$ & $82 \mathrm{a}$ & $76 \mathrm{a}$ & $70 \mathrm{a}$ \\
\hline 6 & $87 \mathrm{a}$ & $90 \mathrm{a}$ & $80 \mathrm{a}$ & $75 \mathrm{~b}$ & $70 \mathrm{a}$ & $68 \mathrm{a}$ \\
\hline $\mathrm{CV}(\%)$ & 10.0 & 6.8 & 14.7 & 7.4 & 7.0 & 14.8 \\
\hline
\end{tabular}

Means followed by the same letter in the column are not significantly different according to the Tukey test at 5\% probability.

Table 3. Vigor (\%) evaluated by the controlled deterioration test in seeds of six lots of cv. Comprida Roxa eggplant.

\begin{tabular}{|c|c|c|c|c|c|c|}
\hline \multirow{3}{*}{ Lots } & \multicolumn{6}{|c|}{ Controlled deterioration } \\
\hline & \multicolumn{3}{|c|}{$24 \mathrm{~h} / 45^{\circ} \mathrm{C}$} & \multicolumn{3}{|c|}{$48 \mathrm{~h} / 45^{\circ} \mathrm{C}$} \\
\hline & $18 \%$ & $21 \%$ & $24 \%$ & $18 \%$ & $21 \%$ & $24 \%$ \\
\hline & \multicolumn{6}{|c|}{ 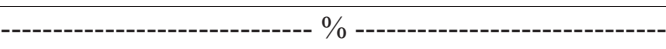 } \\
\hline 1 & $79 \mathrm{a}$ & $86 \mathrm{a}$ & $80 \mathrm{~b}$ & $84 \mathrm{a}$ & $82 \mathrm{a}$ & $66 \mathrm{~b}$ \\
\hline 2 & $83 \mathrm{a}$ & $78 \mathrm{~b}$ & $76 \mathrm{c}$ & $77 \mathrm{~b}$ & $71 \mathrm{~b}$ & $62 \mathrm{~b}$ \\
\hline 3 & $80 \mathrm{a}$ & $70 \mathrm{c}$ & $60 \mathrm{~d}$ & $75 \mathrm{~b}$ & $83 \mathrm{a}$ & $77 \mathrm{a}$ \\
\hline 4 & $82 \mathrm{a}$ & $81 \mathrm{a}$ & $83 \mathrm{ab}$ & $84 \mathrm{a}$ & $74 \mathrm{~b}$ & 73 a \\
\hline 5 & $80 \mathrm{a}$ & $84 \mathrm{a}$ & $96 \mathrm{a}$ & $83 \mathrm{a}$ & $76 \mathrm{~b}$ & $83 \mathrm{a}$ \\
\hline 6 & $69 \mathrm{~b}$ & $78 \mathrm{a}$ & $87 \mathrm{a}$ & $82 \mathrm{a}$ & $80 \mathrm{a}$ & $80 \mathrm{a}$ \\
\hline CV (\%) & 8.3 & 7.5 & 8.2 & 6.0 & 10.0 & 8.9 \\
\hline
\end{tabular}

Means followed by the same letter in the column are not significantly different according to the Tukey test at $5 \%$ probability.
In the electrical conductivity test, it can be seen that at $25{ }^{\circ} \mathrm{C}$ using 25 seeds and varying from 50 and $75 \mathrm{~mL}$, the combination of 25 seeds and $50 \mathrm{~mL}$ was the most sensitive for separating lots into levels of vigor (Table 4). After four hours imbibition, a greater differentiation of lots for seed vigor was observed. It is worth pointing out the similarity in ranking of the lots, both for the periods of four and 24 hours imbibition, indicating that the conductivity showed the same tendency during these periods, allowing the TST to be done in a shorter time and, consequently, obtaining results faster. Similar results were found with eggplant (Alves et al., 2012), bell pepper (Oliveira and Novembre, 2005) and zucchini (Dutra and Vieira, 2006) seeds, where the lots were classified with 8 and 24 hours of imbibition. 
Table 4. Electrical conductivity $\left(\mu \mathrm{S} . \mathrm{cm}^{-1} \cdot \mathrm{g}^{-1}\right)$ using 25 seeds, at imbibition volumes of 50 and $75 \mathrm{~mL}$ of water, at $25{ }^{\circ} \mathrm{C}$ for different imbibition periods.

\begin{tabular}{cccccccc}
\hline & \multicolumn{7}{c}{ Imbibition periods (hours) } \\
\cline { 2 - 8 } Lots & 1 & 2 & 4 & 6 & 12 & 16 & 24 \\
\hline 1 & $24.7 \mathrm{a}$ & $17.8 \mathrm{a}$ & $28.5 \mathrm{a}$ & $29.8 \mathrm{a}$ & $32.5 \mathrm{a}$ & $32.4 \mathrm{a}$ & $33.2 \mathrm{a}$ \\
2 & $48.3 \mathrm{~b}$ & $68.5 \mathrm{~b}$ & $72.3 \mathrm{c}$ & $77.5 \mathrm{c}$ & $88.3 \mathrm{c}$ & $89.9 \mathrm{c}$ & $87.5 \mathrm{c}$ \\
3 & $98.6 \mathrm{c}$ & $100.8 \mathrm{c}$ & $129.3 \mathrm{~d}$ & $130.2 \mathrm{~d}$ & $154.4 \mathrm{~d}$ & $153.3 \mathrm{~d}$ & $137.3 \mathrm{~d}$ \\
4 & $25.6 \mathrm{a}$ & $48.3 \mathrm{ab}$ & $59.2 \mathrm{~b}$ & $60.2 \mathrm{~b}$ & $70.8 \mathrm{~b}$ & $72.5 \mathrm{~b}$ & $70.9 \mathrm{~b}$ \\
5 & $38.2 \mathrm{a}$ & $39.2 \mathrm{a}$ & $40.3 \mathrm{a}$ & $52.5 \mathrm{a}$ & $53.8 \mathrm{a}$ & $54.9 \mathrm{a}$ & $53.8 \mathrm{a}$ \\
6 & $25.3 \mathrm{a}$ & $37.1 \mathrm{a}$ & $38.2 \mathrm{a}$ & $40.5 \mathrm{a}$ & $42.8 \mathrm{a}$ & $43.4 \mathrm{a}$ & $42.9 \mathrm{a}$ \\
\hline CV (\%) & 10.6 & 12.3 & 9.3 & 9.7 & 11.3 & 12.6 & 8.9 \\
\hline Lots & 1 & 2 & 4 & 6 & 12 & 16 & 24 \\
\hline 1 & $13.9 \mathrm{a}$ & $15.8 \mathrm{a}$ & $17.8 \mathrm{a}$ & $18.5 \mathrm{a}$ & $20.5 \mathrm{a}$ & $20.9 \mathrm{a}$ & $20.5 \mathrm{a}$ \\
2 & $30.5 \mathrm{~b}$ & $32.8 \mathrm{~b}$ & $39.8 \mathrm{~b}$ & $40.6 \mathrm{~b}$ & $55.2 \mathrm{~b}$ & $64.8 \mathrm{~b}$ & $64.3 \mathrm{~b}$ \\
3 & $50.9 \mathrm{~b}$ & $63.8 \mathrm{c}$ & $78.9 \mathrm{c}$ & $88.9 \mathrm{c}$ & $95.6 \mathrm{c}$ & $95.8 \mathrm{c}$ & $92.9 \mathrm{c}$ \\
4 & $13.9 \mathrm{a}$ & $25.3 \mathrm{a}$ & $37.8 \mathrm{a}$ & $39.5 \mathrm{a}$ & $39.6 \mathrm{a}$ & $40.8 \mathrm{a}$ & $38.9 \mathrm{a}$ \\
5 & $16.9 \mathrm{a}$ & $37.5 \mathrm{a}$ & $38.8 \mathrm{a}$ & $41.6 \mathrm{a}$ & $42.8 \mathrm{a}$ & $43.9 \mathrm{a}$ & $43.6 \mathrm{a}$ \\
\hline CV (\%) & $14.8 \mathrm{a}$ & $25.8 \mathrm{a}$ & $27.9 \mathrm{a}$ & $39.8 \mathrm{a}$ & $40.8 \mathrm{a}$ & $40.3 \mathrm{a}$ & $40.9 \mathrm{a}$ \\
\hline
\end{tabular}

Means followed by the same letter in the column are not significantly different according to the Tukey test at $5 \%$ probability.

\section{Conclusions}

The accelerated aging test for eggplant seeds should be done by the traditional method for 48 hours at $41^{\circ} \mathrm{C}$.

For the controlled deterioration test, a combination of $24 \%$ water content for 24 hours at $45^{\circ} \mathrm{C}$ is recommended.

The electrical conductivity test should be done using 25 seeds immersed in $50 \mathrm{~mL}$ of distilled water for four hours at $25^{\circ} \mathrm{C}$.

\section{Acknowledgements}

To FAPESP (Fundação de Amparo à Pesquisa do Estado de São Paulo) for the financial support.

\section{References}

ALVES, C.Z.; GODOY, A.R.; CANDIDO, A.C.S.; OLIVEIRA, N.C. Teste de condutividade elétrica na avaliação do potencial fisiológico de sementes de berinjela. Ciência Rural, v.42, n.6, p.975-280, 2012. http://www.scielo.br/ $\mathrm{pdf} / \mathrm{cr} / \mathrm{v} 42 \mathrm{n} 6 / \mathrm{a} 17012 \mathrm{cr} 5424 . \mathrm{pdf}$

ASSOCIATION OF OFFICIAL SEED ANALYSTS. Seed vigor testing handbook. Lincoln: AOSA, 2002. 105p. (Contribuition, 32).

ÁVILA, P.F.V.; VILLELA, F.A.; ÁVILA, M.S.V. Teste de envelhecimento acelerado para avaliação do potencial fisiológico de sementes de rabanete. Revista Brasileira de Sementes, v.28, n.3, p.52-58, 2006. http://www.scielo. $\mathrm{br} / \mathrm{pdf} / \mathrm{rbs} / \mathrm{v} 28 \mathrm{n} 3 / 08 . \mathrm{pdf}$
BAALBAKI; S.E.; MARCOS-FILHO, J.; McDONALD, M.B. (Org.). Seed vigor tests handbook. Ithaca, NY, USA: AOSA, p.186-200, 2009.

BHERING, M.C.; DIAS, D.C.F.S.; GOMES, J.M.; BARROS, D.I. Métodos para avaliação do vigor de sementes de pepino. Revista Brasileira de Sementes, v.22, n.2, p.171-175, 2000. http://www.abrates.org.br/revista/ artigos/2000/v22n2/artigo23.pdf

BRASIL. Ministério da Agricultura, Pecuária e Abastecimento. Regras para análise de sementes. Ministério da Agricultura, Pecuária e Abastecimento Secretaria de Defesa Agropecuária. Brasília, DF: MAPA/ACS, 2009. 395p. http://www.agricultura.gov.br/arq editor/file/laborat\%c3\%b3rio/sementes/ regras $\% 20$ para $\% 20$ analise $\% 20 \mathrm{de} \% 20$ sementes.pdf

CARVALHO, N.M.; NAKAGAWA, J. Sementes: ciência, tecnologia e produção. 4.ed. Jaboticabal: FUNEP, 2000, 588p.

DELOUCHE, J.C.; BASKIN, C.C. Accelerated aging techniques for predicting the relative storability of seed lots. Seed Science and Technology, v.1, n.2, p.427-452, 1973.

DUTRA, A.S.; VIEIRA, R.D. Teste de condutividade elétrica para avaliação do vigor de sementes de abobrinha. Revista Brasileira de Sementes, v.28, n.2, p.117-122, 2006. http://www.scielo.br/pdf/rbs/v28n2/a15v28n2.pdf

FILGUEIRA, F.A.R. Novo manual de olericultura: agrotecnologia moderna na produção e comercialização de hortaliças. Viçosa, MG: UFV, 2008. 421p.

INTERNATIONAL SEED TESTING ASSOCIATION - ISTA. Handbook of vigour test methods. 3.ed. Zurich, 1995, 117p.

JIANHUA, Z; McDONALD, M.B. The saturated salt accelerated aging test for small-seeded crops. Seed Science and Technology, v.25, n.1, p.123-131, 1997.

MARCOS-FILHO, J. Fisiologia de sementes de plantas cultivadas. Piracicaba: FEALQ, 2005. 495p. 
OLIVEIRA, S.R.S.; NOVEMBRE, A.D.L.C. Teste de condutividade elétrica para as sementes de pimentão. Revista Brasileira de Sementes, v.27, n.1, p.31-36, 2005. http://www.scielo.br/pdf/rbs/v27n1/25178.pdf

PANOBIANCO, M.; MARCOS-FILHO, J. Comparação entre métodos para avaliação da qualidade fisiológica de sementes de pimentão. Revista Brasileira de Sementes, v.20, n.2, p.306-310, 1998.

PANOBIANCO, M.; MARCOS-FILHO, J. Envelhecimento acelerado e deterioração controlada em sementes de tomate. Scientia Agrícola, v.58, n.3, p.525-531, 2001. http://www.scielo.br/pdf/sa/v58n3/a14v58n3.pdf

POWELL, A.A. The controlled deterioration test. In: van de VENTER, H.A. (Ed.). Seed Vigour Testing Seminar. Copenhagen. The International Seed Testing Association. p.73-87, 1995.

RODO, A.B.; PANOBIANCO, M.; MARCOS-FILHO, J. Metodologia alternativa do teste de envelhecimento acelerado para sementes de cenoura. Scientia Agrícola, v.57, n.2, p.289-292, 2000. http://www.scielo.br/pdf/sa/ v57n2/v57n2a15.pdf
ROSSETTO, C.A.V.; FERNANDES, E.M.; MARCOS-FILHO, J. Metodologias de ajuste do grau de umidade e comportamento das sementes de soja no teste de germinação. Revista Brasileira de Sementes, v.17, n.2, p.171-178, 1995.

TORRES, S.A.; NEGREIROS, M.Z. Envelhecimento acelerado em semente de berinjela. Revista Brasileira de Sementes, v.30, n. 2, p.209-213, 2008. http://www.scielo.br/pdf/rbs/v30n2/a26v30n2.pdf

TORRES, S.B. Envelhecimento acelerado em sementes de pepino com e sem solução salina saturada. Horticultura Brasileira, v.23, n.2, p.303-306, 2005. http://www.scielo.br/pdf/hb/v23n2/25073.pdf

VIEIRA, R.D.; KRZYZANOWSKI, F.C. Teste de condutividade elétrica. In KRZYZANOWSKI, F.C.; VIEIRA, R.D.; FRANÇA-NETO, J.B. Vigor de sementes: conceitos e testes. Londrina: ABRATES, p.1-21. 1999. 